\title{
Educating Medical Students Regarding the Use of Placebo in Clinical Practice and Research [Letter]
}

This article was published in the following Dove Press journal:

Advances in Medical Education and Practice

\section{Reem Moussa}

St George's University of London, London, UK
Correspondence: Reem Moussa St George's University of London, London, UK

Tel +44 734I 333298

Email reemgmoussa@hotmail.co.uk

\section{Dear editor}

I read with interest the article by Bayoumy et $\mathrm{al}^{1}$ discussing the knowledge and attitudes by medical and nursing students regarding the use of placebo. Bayoumy found that overall knowledge was poor and attitudes varied depending on the speciality within which the placebo was used. As a medical student, I believe this is an important topic to discuss as placebo plays a vital role in research and clinical practice, however wanted to address certain aspects of the paper.

The sample size used included 91 male medical students who had received prior ethics teaching. This means that it could have exhibited response bias, ${ }^{2}$ suggesting that the study lacks internal validity, as the knowledge of placebo in this group may be higher than that within the general population. Furthermore, the inclusion criteria included students who had "finished professional years and started professional years of study" - clarification of this is needed to explain the level of study at which these students are. Additionally, all of the students were at an educational level of 5 and above; it is unclear what it is equivalent to in other countries. Nonetheless, the results indicate that students entering clinical years lack knowledge on placebo. These results can inform universities that teaching on placebo should be introduced at pre-clinical level and subsequently assessed during clinical years in the format of verbal role-play examinations. This would provide students with not only sufficient knowledge on the ethical considerations associated with placebo, but also increase its effectiveness if used as the authors found that 'listening carefully and expressing true concern for patients' increased its effectiveness - all traits that can be assessed in an exam setting.

The authors found that medical students displayed significantly less knowledge about placebo compared to nursing students $(P=0.029)$, despite doctors often being in charge of prescribing compared to nurses. For example, Howick et $\mathrm{al}^{3}$ found that $97 \%$ of primary care practitioners had used placebo at least once in their career. This indicates that doctors are potentially prescribing medications that they are not sufficiently educated about. The General Medical council currently does not issue any guidance on the use of placebo in clinical practice, ${ }^{4}$ therefore it may be beneficial to implement guidelines to provide standardised guidance to all doctors in order to tackle ethical dilemmas surrounding its use.

Of note, the study was cross-sectional and therefore cannot explain at which point students gained knowledge of placebo, although $26 \%$ of medical students stated that they received their knowledge from "college" ${ }^{5}$ More detail is required to 
inform the audience of when and how the students received their education on placebo in order allow universities to introduce suitable methods of delivering teaching on the subject.

In conclusion, this research has highlighted a gap in medical and nursing school curricula. I believe that teaching on the use of placebo should be embedded into the curriculum and examined to increase its overall effectiveness in clinical practice. I also believe that national guidelines should be implemented to provide clarity to healthcare professionals regarding its use.

\section{Disclosure}

The author reports no conflicts of interest for this communication.

\section{References}

1. Bayoumy H, Almuwallad G, Eissa A. Investigating knowledge, attitude, and beliefs regarding placebo interventions in clinical practice: a comparative study of nursing and medical university students. Advan Med Educ Pract. 2020;11:619-635. doi:10.2147/AMEP.S250019

2. Sedgwick P. Non-response bias versus response bias. BMJ. 2014;348: g2573-g2573. doi:10.1136/bmj.g2573

3. Howick J, Bishop F, Heneghan C, et al. Placebo use in the united kingdom: results from a national survey of primary care practitioners. PLoS One. 2013;8(3):e58247. doi:10.1371/journal.pone.0058247

4. GMC guidance tightens prescribing rules. Pharm J. 2013. Available from: http://gmc-uk.org/-/media/documents/Prescribing_guidance.pdf_ 59055247.pdf.

5. Sedgwick P. Cross sectional studies: advantages and disadvantages. BMJ. 2014;348:g2276-g2276. doi:10.1136/bmj.g2276

Dove Medical Press encourages responsible, free and frank academic debate. The content of the Advances in Medical Education and Practice 'letters to the editor' section does not necessarily represent the views of Dove Medical Press, its officers, agents, employees, related entities or the Advances in Medical Education and Practice editors. While all reasonable steps have been taken to confirm the content of each letter, Dove Medical Press accepts no liability in respect of the content of any letter, nor is it responsible for the content and accuracy of any letter to the editor.

\section{Publish your work in this journal}

Advances in Medical Education and Practice is an international, peerreviewed, open access journal that aims to present and publish research on Medical Education covering medical, dental, nursing and allied health care professional education. The journal covers undergraduate education, postgraduate training and continuing medical education including emerging trends and innovative models linking education, research, and health care services. The manuscript management system is completely online and includes a very quick and fair peer-review system. Visit http://www.dovepress.com/testimonials.php to read real quotes from published authors. 